UDC 372.881.111.1

DOI https://doi.org/10.24919/2308-4863/43-1-18

Yuliia BILENKA,
orcid.org/0000-0001-7909-5070
Lecturer at the Department of English and Methods of its Teaching
Uman State Pavlo Tychyna Pedagogical University
(Uman, Cherkasy region, Ukraine) yuliabil91@gmail.com

Malvina KOLOMIIETS, orcid.org/0000-0002-6891-6061

Lecturer at the Department of English and methods of its teaching Uman State Pavlo Tychyna Pedagogical University

(Uman, Cherkasy region, Ukraine) m.kolomiiets@udpu.edu.ua

\title{
THE ROLE OF HOME READING AND HOME SCREENING IN FOREIGN LANGUAGE LEARNING BY STUDENTS OF LANGUAGE DEPARTMENTS
}

\begin{abstract}
The issue we consider in this paper is the role of home reading and home watching in foreign language teaching and its organization in foreign language classes. We would like to make a reservation at once, the concept of home work is reading or watching a work in a foreign language in the origin. It seems to us that only the language of works of art, corresponding, as a rule, to the norms of modern language, is an irreplaceable model in the study of a foreign language, and the role of this model is especially great. By reading a book written in such a language, the student has the opportunity to observe the existence of language in the language of the author and his characters, to follow the ways of expressing thoughts in a foreign language and directly perceive the meaning of what is read. The book also builds on the visual perception of the message, which is especially important for those whose visual perception is better developed than auditory.

Criteria of choosing material and stages of working with it are presented in the article. We consider that all the aspects can be implied in both- reading and writing.

This paper considers reading and home viewing as an independent type of language activity in the process of learning foreign languages. Theoretical bases of teaching reading, its psychological and linguistic features and classification of types are described.

The second section considers home reading as a means of developing language reading skills, gives a general description, discusses the functions and tasks, as well as presents the stages of work on home reading.

The peculiarities of working with films for home viewing are also investigated and the effectiveness of both activities is determined.
\end{abstract}

Key words: language, book, activity, student, home task, education.

Юлія БІЛЕНЬКА, orcid.org/0000-0001-7909-5070 викладач кафедри англійської мови та методики ї̈ навчання Уманського державного педагогічного університету імені Павла Тичини (Умань, Черкаська область, Україна) уuliabil91@gmail.com

Мальвіна КОЛОМІЕЦЬ, orcid.org/0000-0002-6891-6061 викладач кафедри англійської мови та методики ії навчання Уманського державного педагогічного університету імені Павла Тичини (Умань, Черкаська область, Україна) m.kolomiiets@udpu.edu.иа

\section{РОЛЬ ДОМАШНЬОГО ЧИТАННЯ ТА ДОМАШНЬОГО ПЕРЕГЛЯДУ ФІЛЬМІВ У ВИВЧЕННІ ІНОЗЕМНОЇ МОВИ СТУДЕНТАМИ МОВНИХ СПЕЦІАЛЬНОСТЕЙ}

Питання, яке ми розглядаємо в цій роботі, - роль домашнього читання та домашнього перегляду фільмів у навчанні іноземної мови, організація на заняттях з іноземної мови. Концепція домашньої роботи - це читання або перегляд твору іноземною мовою, тобто мовою оригіналу. Нам здається, щзо лише мова творів мистецтва зазвичай відповідає нормам сучасної мови, є незамінною моделлю у вивченні іноземної мови, роль цієї моделі особливо велика. Коли здобувач освіти читає книгу, написану такою мовою, він має можливість спостерігати за мовою автора та його героїв, стежити за способами вираження думок іноземною мовою, безпосередньо 
сприймати значення того, щчо читає чи чує. Робота із книгою також спирається на візуальне сприйняття повідомлення, щзо особливо важливо для тих, у кого зорове сприйняття розвинене краще, ніж слухове.

Критерії вибору матеріалу й етапи роботи з ним представлені у статті. Ми вважаємо, що всі аспекти можуть бути застосовані під час як читання, так і перегляду.

У иій роботі читання та домашній перегляд розглядаються як самостійний вид мовної діяльності у процесі вивчення іноземних мов. Описано теоретичні основи навчання читання, його психологічні та мовні особливості, класифікаиію типів.

У другому розділі розглянуто домашне читання як засіб розвитку навичок читання, дано загальну характеристику, зазначено функиії та завдання, а також представлено етапи роботи з домашнього читання.

Також досліджуються особливості роботи з фільмами для домашнього перегляду, визначається ефективність обох видів діяльності для розширення словникового запасу здобувача та впровадження його в повсякденне спілкування засобами складання діалогів, дискусій після перегляду матеріалу й опрацювання лексики.

Ключові слова: мова, книга, діяльність, учень, домашнє завдання, освіта.

Introduction. Knowledge of a foreign language is a criterion necessary for a successful career in today's world. In this regard, the importance of a foreign language as a subject in schools, institutions of additional and higher education institutions is increasing.

The ability to speak a foreign language gives the opportunity to study at prestigious foreign universities, attend international conferences and competitions, as well as travel the world without experiencing difficulties and inconveniences in communication.

Reading books in the original is very useful for anyone wishing to learn a foreign language. It is in foreign literature that the most complete idea of the speakers of this language fits because it reflects the history of the people, life, and worldview. At the same time, the discrepancy of any facts of reality testifies to the national identity of the languages being studied, just as the coincidence of facts often testifies to the commonality of traditions, customs, norms of behavior inherent in the respective ethnic groups.

In the development of skills and needs of foreign language reading, the formation of students "psychophysiological mechanisms of reading as an activity, process, as well as in improving students" oral language skills based on reading home reading is designed to play a leading role. Independent reading of foreign language literature for students should become an integral, equivalent component of the whole pedagogical process of learning foreign languages. Abundant reading about yourself will allow you to pass through the minds of students per unit time a large number of language combinations grammatical structures and lexical combinations so that then in the process of oral processing of the lesson formed the necessary rhetorical "traces" of the main mass is the text of speech and speech material. Being an indispensable and inexhaustible source of a variety of extralinguistic information, literary works expand the general horizons of students and, communicating material for independent derivation and, creates a natural basis for the development of their thinking. Touching on the most interesting and relevant issues of our time, covering historical events, being rich in plot associations, the literary work does not cause only mental operations, but requires "exit" to communication, and is therefore also the basis for developing oral skills, because it creates psychological prerequisites for speaking, the communicative orientation of learning.

Watching movies can really be a great way to hone your language skills. Plus, it's easier today than ever with streaming online services and digital TV. From experience, I can say that students who are regularly exposed to live English - especially when watching movies - often feel more confident in communication. However, for some, the transition to watching movies in the original may seem too big a step. In this article, we will look at what, how, and why to look to improve your English.

The relevance of this work is due to the current trend of the growing interest of students in learning foreign languages, watching movies and TV series with the original soundtrack, as well as reading authentic foreign literature.

The practical significance of studying this problem is to create conditions under which the organization of educational activities can increase the effectiveness of foreign language learning, realizing its main purpose - the formation of communicative competence.

The object of study of this work is reading and watching as types of foreign language activities.

The subject of research is home reading and home watching as a means of learning a foreign language.

The purpose is to study the features and determine the role in foreign language education.

Reading today is the most realistic form of using language competence acquired at school. In order to apply the oral language skills acquired in school, a student needs at least one interlocutor with whom he will meet regularly, which is very problematic in our environment. A student of any school (gymnasium, lyceum) can do it independently, one on one with a book, magazine, newspaper, and it will open new perspectives 
for him in educational, professional, and personal development. But presented to himself, he will read in a foreign language only if it is not a difficult lesson for him (in other words, if he has a well-developed reading technique) and if this lesson is interesting to him, gives him pleasure. And such a result can be reached only by achieving it thoughtfully and systematically from the very beginning of learning a foreign language.

Today, methodologists, depending on the target setting, distinguish four types of reading: viewing, introductory, study, and search. Training in all four of these types is included in the foreign language curriculum.

Review reading involves getting a general idea of the topic and the range of issues addressed in the text. It is a coherent, selective reading, reading the text in blocks for a more detailed acquaintance with its "focusing" details and parts.

As for introductory reading, it is a cognitive reading, in which the subject of attention of the reader is the whole language work (book, article, story) without the intention to obtain certain information. This is a reading "for yourself", without prior special installation for further use or reproduction of the received information.

Study reading involves the fullest and most accurate understanding of all information contained in the text and its critical interpretation. This is a thoughtful and unhurried reading, which involves a purposeful analysis of the content of the text, which is read based on linguistic and logical connections. Its task is to form a skill that learns to overcome difficulties in understanding a foreign text. The object of "study" seeing this reading is the information contained in the text, but not linguistic material.

Speaking of search reading, we would like to note that it is focused on reading newspapers and literature in the specialty. Its purpose is to quickly find in the text and in the array of texts quite specific data (facts, characteristics, descriptions, figures, instructions).

Home reading itself combines all the types of reading mentioned above. As for its goals and objectives, it should be noted that on the one hand it is instilled in students the skills and abilities to read literature in a foreign language, and on the other hand, the development of skills and abilities of language and writing.

Taking into account the interests of students and their level of proficiency in a foreign language, the availability of reading material, as well as some tips available in the methodological literature can offer the following basic options for home reading:

I)individualized home reading, when each student works on his own text, chosen by him or by the teacher according to his interests.
II) general class home reading, when the whole class reads a common text for all, but with different tasks and settings for reading depending on the language skills of students.

In both versions of independent home reading, there is no need for their topics to correspond to the lexical and conversational topics studied at this stage. However, the topic of home reading should be limited, as a rule, to exemplary topics for oral language and reading, provided by the curriculum.

On the part of the goal in the organization in the organization of home reading at this time identified two trends:

1) reading in order to understand the text;

2) reading as preparation for a conversation on what is read.

This second direction is not the main and constant in the characterization of reading as a type of language activity. It is introduced into reading by the practical orientation of the educational process of teaching foreign languages to the development of oral language.

Based on the purpose of teaching foreign languages, organization of home reading, taking into account the above, it is necessary to distinguish between two stages. The first stage is self-reading as a process of obtaining information from the text. This stage is mandatory in the work on any text. The second stage is a conversation based on home reading material. This stage of work should be selective and apply only to some of the most relevant to language practice texts or fragments thereof.

In-home reading lessons you should try to use all kinds of language activities: speaking, listening, writing, translation. There are two main elements of working with text in each lesson:

1) check comprehension of what is read;

2) development of oral language on the basis of reading (monologue, dialogue, discussion).

Watching movies in English is one of the most enjoyable ways to learn English. We just lie on the couch watching a nice movie and $\langle\ldots\rangle$ learning English? This is true if you are fluent in the language and understand English as well as your native language. If you are just learning a language, you have to work a little.

\section{Criteria for selecting texts for home reading}

The teacher's work on the home reading lesson begins with the choice of literary material. His correct choice largely determines the further results of the work. The following features of students should be considered at a choice:

1) their interests, determined by age, cultural level;

2) the degree of language proficiency. 
Literary material should be interesting to the student, available to him for understanding, but not be primitive. As such material, it is more expedient to choose short stories, stories, or short stories, divided into separate sections. In this lesson, you can consider all aspects of the selected literary work, to conduct all kinds of work on it.

A fundamental requirement for texts to read is their passivity and accessibility for students. However, the strength of the text does not mean lightness. Excessive simplification of the text reduces its instructive value. Psychologists note that the most effective is such training in any activity that requires high stress on the psyche of the individual, the mobilization of his will and attention. It is known that the psyche functions intensely when the performance of activities is associated with any difficulties (Король говорить). In addition, reading is subject to self-regulation, the reader himself can facilitate the conditions of the activity and thus ensure the implementation of the task before him the extraction of information. It should also be noted that the ability of texts to read is determined not only by the language and life experience of the student, but also the type of reading for which the text is intended.

Texts for home reading can be more complex than texts for, for example, those who study reading in class. The student is working on homework is not limited in time, has the opportunity to use a dictionary or additional literature at its discretion.

Another important requirement for texts is the requirement of instructive value of the text. The instructive value of the text means its educational, educational, and practical value. The practical value is determined by the effectiveness of the text as a means of developing reading skills. Requirements for the language form of texts for reading vary depending on the type of reading. Therefore, although the readability of the text is also determined by the amount of difficulty to understand linguistic material and unexplored linguistic phenomena, the implementation of this requirement will be different. First of all, the difficulties of cognition of the studied linguistic phenomena will be determined not by sound but by graphic form. There are many special manuals, textbook supplements, collections of stories, fairytales for home reading. The texts in them are adapted to the level of high school. But not always textbooks, collections, stories are enough to create in students a holistic picture of the richness and diversity of the literary fund of the country of the language being studied. There is a need to expand the choice of literature for home reading lessons.

N. A. Selivanova advises applying a systematic approach to the selection of literary texts for home reading, which will create a clearer and deeper understanding of the fiction of countries and the language studied through acquaintance with the works included in the golden fund of national literature: children's, youth and so-called "adult" literature, loved by teenagers.

As mentioned above, for home reading it is better to choose short stories and short stories for more than a complete and comprehensive acquaintance with them. However, more voluminous works, novels, short stories should also not be overlooked, and acquaintance with the whole work is optional.

A holistic approach can be provided by a comprehensive reading of individual parts of the work, which does not lose a sense of wholeness. These parts can be called text fragments. When selecting text fragments it is necessary to take into account the interest of students in the storyline of the development of the behavior of literary characters. It is desirable that each text corresponds to a significant moment for the disclosure of the plot conflict. There are five known key points: exposure, connection, vicissitudes (development of action), culmination, denouement.

The main criteria for selecting episodes include the following

- the significance of the episode in the development of the overall idea of the work;

- problematic, the presence in the episode of a problematic situation, which serves as an effective incentive to penetrate into the essence of the conflict, increases reading motivation, creates a certain psychological mood, contributing to the language activity of students;

- extralinguistic informativeness (we are talking about the subject of the work of art). In this case, the theme is not the range of events that create the life basis of the works, and those phenomena of reality, which are the essence of what happens to the characters: moral and ethical themes of good and evil, friendship, love, justice;

- ethnographic value, in some fragments, should include, if possible, episodes that reveal to students those or other phenomena of reality, which are specific to the country of the language being studied.

It is important to emphasize that home reading texts can be of different styles and each style is characterized by its own special scheme.

Therefore, the suitability of texts or parts of them for work in the lesson of home reading and language practice with them can be determined by the following criteria:

1) a bright and interesting plot of the text or passage;

2) emotionality and imagery of presentation; 
3) the relevance of the material;

4) thematic proximity of the subject to the life experience and interests of students;

$5)$ the possibility of various situational transformations of the content of the text or passage.

Depending on the purpose and nature of language practice in some cases to determine the suitability of the text may be sufficient to meet only two or three of these criteria.

Stages of working on the text and exercises in-home reading lessons

There are different points of view about what stages of work on the text should be included in the learning process, which is most effective. Naturally, the chosen types of work depending on the goals we set for reading.

Some methodologists, based on the purpose of teaching foreign languages in the organization of home reading distinguish two stages.

The first stage is self-reading as a process of obtaining information from the text. This stage is mandatory in the work on any text. However, at this stage, the work on most of the texts offered to students for independent home reading should be completed.

The second stage is a conversation based on home reading material. This stage of work should be selective and apply only to some of the most suitable for language practice texts or their fragments.

Some methodologists consider it inexpedient to use forms and methods of work that turn reading control into work on the development of oral skills or translation skills. Therefore, he uses language exercises only as a means to test comprehension. The lesson includes three stages:

1) control of understanding of the general maintenance;

2) checking the understanding of some essential details;

3) evaluation of what was read.

In a more traditional method, there are usually 3 stages of work on any text: pre-text stage (anticipation stage), text stage, post-text stage. Obviously, the posttext stage will be present when the text is seen not so much as a means of forming reading skills, but for the development of productive skills in oral or written language, but simply put, the ability to speak and write in a foreign language.

Thus, we did not follow any approach, the sequence of work on the text will be approximate as follows: pre-speech exercises, control of the concept of content (text stage), control of the concept of important details of the text (analysis and evaluation, post-text stage), analysis of literary and stylistic features.
There is no agreement between methodologists and the need for pre-text exercises aimed at working with the lexical and grammatical structures used in the text. Some authors believe that such exercises are mandatory and they should precede the discussion of the text itself because it enriches students' vocabulary and prepares the basis for further discussion of the problem. Other authors believe that reading is an independent type of speech activity, not a means of learning oral speech, so preliminary work on words will be superfluous (Ischuk, 1998).

Reading works of fiction in a foreign language in home reading should be aimed at developing selfreading skills and gradually bring students to the ability to read original literature (the literature that exists in the real functioning of the language).

The practice of teaching and the multi-purpose nature of home reading requires you to focus work on the text material read at home in one separate lesson and collection, also to increase the frequency of home reading lessons (for example, 1 lesson out of four). Only in this way you can maintain interest in the material read and ensure the development of appropriate speech skills.

The term "test lesson on home reading", unfortunately, is quite firmly entrenched in the practice of schooling and even language exercises are sometimes suggested to be used only as a means of understanding what is read, which significantly reduces students' interest in this aspect. We must not forget about the educational nature of the aspect of "home reading", where the content itself and properly organized work with it should serve as a powerful incentive to increase the motivation to learn.

It seems that if in the course of learning the language in the selection of material for home reading to put the literary and regional approach, it will be much more effective in terms of teaching reading and speaking, and in terms of improving the cultural and educational level of students. Consideration of linguistic, and extralinguistic characteristics of literary texts gives grounds to assert that in the course of in-depth study of foreign languages home reading should be conducted on works of fiction of the country of the language being studied (Бев3, 2014: 125).

Taking into consideration all these factors we have had the practice of working with "The Picture of Dorian Gray" by Oscar Wilde. The book is worth using as material full of usable lexical minimum.

Practicing it first half of educational year by students of faculty of foreign languages for three years we examined that "The Picture of Dorian Gray" by Oscar Wilde can be taken as a good example of the material of home reading. Applicants show the following statistics by questionnaire: 


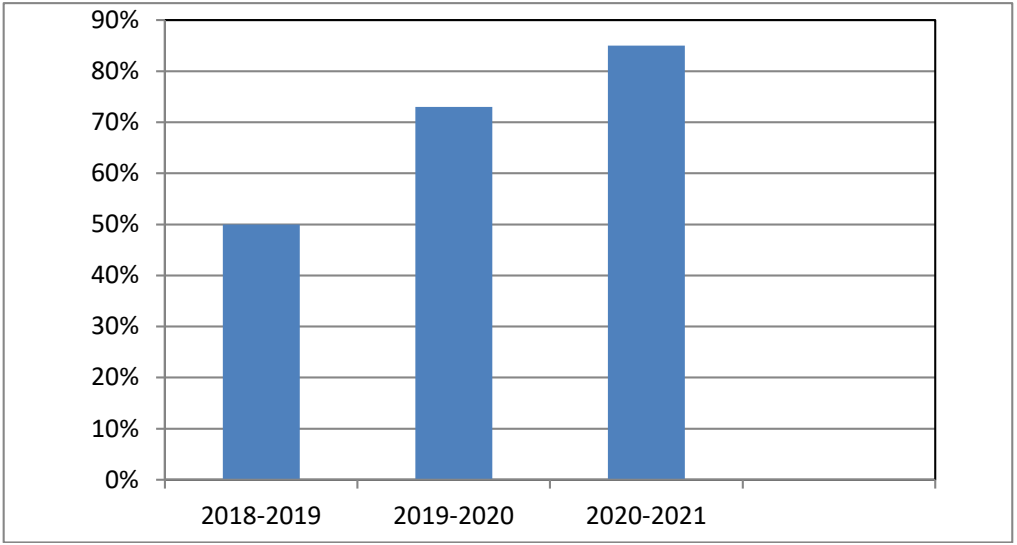

Fig. 1. Efficiency of using new lexical units

Usage of vocabulary that has become active has increased since the beginning of applying this source from 50 to $85 \%$. More than 100 students were included in the questionnaire.

Reading, as one of the sources of information, plays a significant role in human life. The purpose of reading is to comprehend the speech message that is visually perceived. The process of reading is a process of perception and active processing of information, graphically encoded by the system of any language. Learning to read contributes to the implementation of almost all major aspects of education - mental, ethical, aesthetic and labor. It promotes the development of figurative and logical thinking, imagination, attention, memory.

Home reading lessons are very important in mastering a foreign language as a means of communication. With the correct organization of classes, students develop an artistic taste, they learn to analyze, summarize, argue using new lexical items.

Home watching as an effective way of improving language proficiency

Watching movies in English is useful as it:

- improves listening comprehension. By listening to real English speech, student learns to understand English by ear. He hears intonation, pronunciation, the rhythm of the speech and each time understands better and better what the actors are talking about on the screen;

- improves pronunciation. Watching movies in English helps improve pronunciation. Even if the person does not repeat the words, but just listens to the characters speak, there is a chance to improve pronunciation. You involuntarily remember how to pronounce the words correctly, and without noticing it, you begin to imitate the intonation and pronunciation of the actors;

- expands vocabulary. When you watch a movie in English and some unfamiliar word appears to you several times, you will of course look at its translation in the dictionary. And remember this word for a long time. Words are easier to remember in context, especially when they are associated with strong emotions. And if your favorite actor said "Damn it" you will definitely remember that it translates as "Damn it!";

- motivates ourselves to learn English. When you watch an interesting film, with an exciting plot, your favorite actors, of course, you want to understand as much as possible. And this desire stimulates you to learn new words to understand grammar, in order to easily understand everything that is being said on the screen.

There are some steps how to properly watch videos in English:

- choose a video of your level.

If you have recently started learning English, you shouldn't watch complicated films in the original. You will understand little and it will not do you any good. It will only upset and discourage the desire to watch films in English in general. In the initial stages, it is better to choose special training videos. You can watch educational series (they use simple words and constructions, the actors speak clearly and understandably, you can understand $70-80 \%$ of the words). The meaning of unfamiliar words will be understood from the general context or from the facial expressions and movements of the actors;

- use subtitles.

Of course, when you watch a video with subtitles, it is easier for you to understand what is at stake. But sometimes you concentrate so much on the subtitles that you don't listen to what the actors are talking about.

Better to watch a movie for the first time without subtitles. Just watch the way you would watch a movie in Russian. Listen, try to understand, but don't translate verbatim;

- memorizing words.

After watching a movie without subtitles, watch it again. Now turn on the credits and prepare a pen with a notebook. As you watch the movie a second time, write down unfamiliar words (you will need to learn and translate them later);

- repeat individual phrases.

It is very useful to repeat the words, sentences, dialogues of the actors. Review a short excerpt. Pause and repeat what you just listened to. Try to imitate intonation, pronunciation, stress in words;

- watch the movie again. 
A few days after you have learned all the new words, watch the movie again. Compare how much more you understand now that you already know words that were previously unfamiliar.

In the English practice classes, we introduced the practice of reading a book at home in the first term and watching movies at home in the second. We have selected films with a modern dictionary, which corresponds to the level of a bachelor's degree student in the language department.

Our students worked with the following material: "The King Speech" (2010) (Король говорить), "Soul” (2020) (Душа), “The break up" (2006) (Розлучення по-американські), “Miss Sloane” (2016) (Небезпечна гра Слоун).

We investigated the effectiveness and preferences of students compared to home reading and obtained the following statistics, where blue is for home reading and red is for home watching accordingly.

We can consider that effectiveness of home watching increased. This is due to the process of digitalization and the desire of students to visually perceive new material. Performing almost identical versions of tasks as in-home reading, students showed more interest and participation in the watching than reading.

Conclusions. The need to master English is becoming increasingly important in today's world, where every fourth inhabitant uses it to communicate at one level or another. The study of this subject is a recognition of the objectively existing social interest in the study of foreign languages and confirmation of the importance of this subject for the implementation of promising tasks of personal development.

\section{BIBLIOGRAPHY}

1. Бевз О. П. Інтерпретація англомовного тексту як засіб фасилітації особистісного саморозвитку студентів старших курсів мовних факультетів. Порівняльно-педагогічні студіï. 2014. № 4. С. 123-128. URL: http://nbuv.gov.ua/UJRN/Ppstud_2014_4_20.

2. Бичкова Н. А. Організація уроків домашнього читання на старшому етапі навчання. Іноземні мови у школі. 2003. № 6. C. 43.

3. Конишева А. В. Контроль результатів навчання іноземної мови. Санкт-Петербург, 2004. 135 с.

4. Мильруд Р. П., Гончаров А. А. Теоретические и практические проблемы обучения пониманию коммуникативного значение иноязычного текста. Иностранные языки в школе. 2003. № 1.

5. Бессерт О. Б. Навчання індивідуального читання : монографія. Архангельськ, 2008. 276 с.

6. Носовичі Є. В., Мильруд Р. П. Параметри автентичного навчального тексту. Иностранные языки в школе. 1999. № 1. C. 11-18.

7. Ishcuk N. The Manual on the Home Reading for the Senior Students of the Secondary School. Англійська мова. 1998. № 4. URL: http://www.online-literature.com/o_henry/ (дата звернення: 17.09.2021).

8. Вивчення англійської за допомогою книжок. Як вивчити англійську внаслідок читання? URL: https://nyschool.org.ua/uk/blog/izuchenie-anglijskogo-s-pomoshhyu-knig/ (дата звернення: 27.10.2021).

9. Король говорить : фільм. URL: https://www.imdb.com/title/tt1504320/ (дата звернення: 28.10.2021).

10. Душа : мультфільм. URL: https://www.imdb.com/title/tt2948372/ (дата звернення: 28.10.2021). 
11. Розлучення по-американські : фільм. URL: https://www.imdb.com/title/tt0452594/ (дата звернення: 16.09.2021).

12. Небезпечна гра Слоун : фільм. URL: https:/www.imdb.com/title/tt4540710/ (дата звернення: 22.09.2021).

\section{REFERENCES}

1. Bevz O. P. Interpretatsiia anhlomovnoho tekstu yak zasib fasylitatsii osobystisnoho samorozvytku studentiv starshykh kursiv movnykh fakultetiv [Interpretation of the English text as a means of facilitating the personal self-development of senior students of language faculties]. Porivnialno-pedahohichni studii, 2014, № 4, pp. 123-128 [In Ukrainian].

2. Bichkova N. A. Orhanizatsiia urokiv domashnoho chytannia na starshomu etapi navchannia [Organization of home reading lessons at the senior stage of study]. Inozemni movy v shkoli, 2003, № 6, p. 43 [In Ukrainian].

3. Konysheva A. V. Kontrol rezultativ navchannia inozemnii movi[Control of foreign language learning outcomes]. SPb., 2004, p. 135 [In Ukrainian].

4. Milrud R. P., Goncharov A. A. Teoreticheskie i prakticheskie problemyi obucheniya ponimaniyu kommunikativnogo znachenie inoyazyichnogo teksta [Theoretical and practical problems of teaching to understand the communicative meaning of a foreign language text]. IYaSH, 2003, № 1 [In Russian].

5. Bessert O. B. Navchannya IndivIdualnomu chitannyu : monograflya [Teaching individual reading : monograph]. Arhangelsk : Arhang. gos. tehn. un-t, 2008, 276 p. [In Russian].

6. Nosovichi E. V., Milrud R. P. Parametri avtentichnogo navchalnogo tekstu [Parameters of the authentic educational text]. IYaSh, 1999, № 1. S. 11-18 [In Russian]. 